\title{
Dr. Reinaldo de Menezes Martins: seis décadas dedicadas à vacinação
}

\author{
Dr. Reinaldo de Menezes Martins: six decades \\ dedicated to vaccination \\ Dr. Reinaldo de Menezes Martins: seis décadas \\ dedicadas a la vacunación
}

doi: 10.1590/0102-311 X00200720

Luiz Antonio Bastos

Camacho 1

Marilia Sá Carvalho 2

Reinaldo de Menezes

Martins ${ }^{+}$

\footnotetext{
${ }^{1}$ Escola Nacional de Saúde Pública Sergio Arouca, Fundação Oswaldo

Cruz, Rio de Janeiro, Brasil.

2 Programa de Computação

Científica, Fundação Oswaldo

Cruz, Rio de Janeiro, Brasil.

Falecido.

\section{Correspondência}

L. A. B. Camacho

Departamento de

Epidemiologia e Métodos

Quantitativos em Saúde, Escola

Nacional de Saúde Pública

Sergio Arouca, Fundação

Oswaldo Cruz.

Rua Leopoldo Bulhões 1480

8o andar, Rio de Janeiro, RJ

21041-210, Brasil.

luiz.camacho@ensp.fiocruz.br
}

Reinaldo de Menezes Martins era médico e doutor em Medicina Tropical. $\mathrm{Na}$ sua carreira de pediatra reconhecido em premiações e homenagens, influenciou a prática médica de gerações de profissionais como preceptor da residência médica e liderança respeitada entre pediatras. Nas últimas duas décadas da sua carreira ampliou a dedicação ao estudo de vacinas em saúde pública, com significativa produção acadêmica, com orientação pragmática, valorizada em consultorias para a Organização Mundial da Saúde (OMS), Fundo das Nações Unidas para a Infância (UNICEF), Ministério da Saúde e o Instituto de Tecnologia em Imunobiológicos da Fundação Oswaldo Cruz (Bio-Manguinhos/Fiocruz). Esta entrevista procurou focar os componentes relacionados a vacinas na biografia de um workaholic, que, de tão produtivo, exigiu esforço de síntese por parte do entrevistado e dos entrevistadores. Dr. Reinaldo faleceu em janeiro de 2019, deixando um legado de contribuições de inestimável valor para a saúde pública, baseadas em evidência científica. 


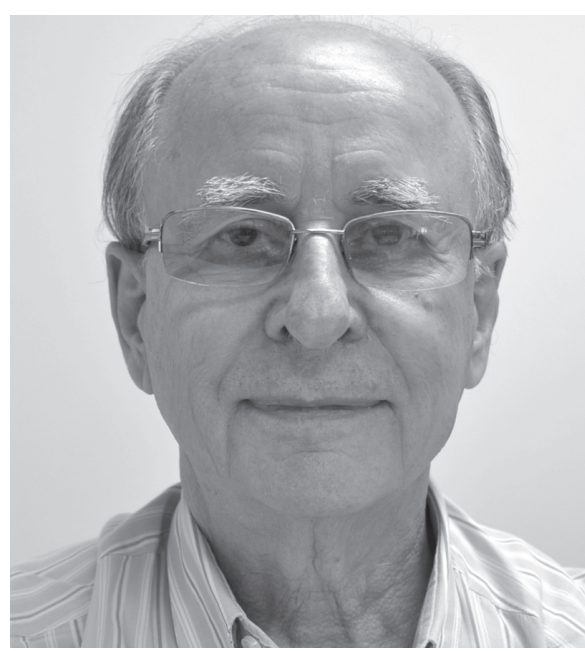

Dr. Reinaldo de Menezes Martins (foto: Assessoria de Comunicação Bio-Manguinhos/Fiocruz).

Camacho Reinaldo, o propósito desta entrevista é fazer um registro informal da sua longa experiência como pediatra, com ênfase na sua atuação na área de vacinas.

Reinaldo Uma biografia da Zilda Arns 1 lançada há pouco tempo mostra uma parte do meu trabalho na área de prevenção. Naquela época, nós estávamos tentando implantar a terapia de reidratação oral e com problemas para aceitação... e com sabotagem do programa [de terapia de reidratação oral]. Esse livro se refere a mim muitas vezes porque foram anos de colaboração. Nós trabalhamos principalmente na linha de aleitamento materno, de terapia de reidratação oral, ações preventivas, parto normal e alojamento conjunto. Aí entraram também as imunizações, mas não como "carro chefe”. Isso é para mostrar o meu envolvimento com as ações preventivas de um modo geral e não somente com as vacinações.

Camacho Em que época foi esse trabalho com a Zilda Arns?

Reinaldo Principalmente na década de 1980, que foi considerada uma década perdida para os economistas. Como começou meu interesse pessoal com a área de prevenção e de vacinas? Eu não fiz residência médica, e na época muito poucas pessoas faziam. Nós fazíamos concurso para o prontosocorro e foi assim que eu entrei no serviço público.

Camacho Isso na década de 1960?

Reinaldo Sim. E em pronto-socorro eu me senti inútil. Primeiro porque eu achava que não tinha aptidão para trabalhar em emergência. Na emergência a pessoa não pode pensar muito, não pode ser reflexiva, e isso é contra o meu feitio. ...Então eu fui trabalhar na maternidade Fernando Magalhães, e depois em posto de saúde. Foi a melhor coisa que me aconteceu porque lá eu me senti útil. Isso não acontecia no pronto-socorro, que era medicina imediatista, sintomática, que não resolvia nada. No posto de saúde eu vi que se podia fazer alguma coisa. Fui trabalhar na Gamboa que era das favelas mais pobres do Rio de Janeiro, uma área de população miserável 2. Ali tinha um albergue de jovens, que eu atendia. E eles não tinham dinheiro. Não adiantava receitar. Eu fiquei muito frustrado também no início e pensava "o que que eu vou fazer aqui?! Eu vou distribuir leite?!". Aí tinha leite para distribuir e era a estratégia para vacinar. Dava leite em troca de vacinar.

Camacho Que vacinas estavam disponíveis nas unidades de saúde naquela época? 
Reinaldo Muito poucas. A vacina de varíola, DTP (do Laboratório Pinheiros que não imunizava contra a coqueluche, mas imunizava bem contra difteria e tétano). Nesse período começou a vacinação de sarampo, que naquela época dava muito. Tinha também o BCG... e não sei se tinha mais alguma.

Camacho BCG era oral ainda?

Reinaldo A BCG, quando eu fui trabalhar, já estava na passagem de oral para intradérmica. Apesar da limitação, as vacinas evitavam muita doença. Principalmente a de sarampo, apesar de ser bastante reatogênica. Mas é claro que a gente não podia focar somente nas vacinas. Para começar eram poucas. Eu lembro que nós não tínhamos remédios. Eu conseguia alguns remédios para distribuir. Remédios simples, como a piperazina para sarna. Tinha muita sarna.

Reinaldo A ideia que nessa época se propagava na saúde pública de um modo geral, com exceções, é que a medicina não tem nada a ver com saúde pública. Que problema é político, é socioeconômico, e as ações médicas são inúteis. Somente saneamento básico poderia resolver as coisas e a melhoria da condição socioeconômica. Eram recomendações e pensamentos de quem não trabalhava realmente no campo. Então eu quis provar para mim mesmo, e para as pessoas, que a medicina pode fazer alguma coisa em benefício da saúde pública. Em especial em pediatria, que é uma área voltada para prevenção, quase que por definição. Essa experiência na Gamboa, e em outras favelas, me fez refletir sobre essa realidade e sobre como implementar ações preventivas como vacinação. E foi uma luta!

Marilia Por que foi uma luta?

Reinaldo Porque os médicos eram instruídos a não vacinar quem estivesse doente, e havia muita contraindicação. Nessa época, o Ciro de Quadros estava fazendo campanha de varíola e eu perguntei para ele numa reunião no Ministério da Saúde quais eram as principais causas de não vacinação no Brasil. Ele botou em primeiro lugar as falsas contraindicações. Isso tudo inviabilizava vacinar. Depois ficavam surpresos que as coberturas eram baixas. Então eu escrevi um artigozinho que foi publicado na Pediatria Moderna 3 falando que as vacinações podem ser dadas em pessoas com pequenas doenças que não comprometessem o estado geral da criança.

Marilia Eu pessoalmente vivi a introdução de todas essas questões nos próprios cursos de saúde pública da ENSP [Escola Nacional de Saúde Pública Sergio Arouca/Fundação Oswaldo Cruz]. Fiz residência em saúde pública lá e acompanhei tudo isso. Eu também sou fruto do esforço de colocar prevenção na vida clínica e clínica no posto de saúde também, que não tinha. Mas a questão da vacina, eu me lembro lá na ENSP, [provocou] uma discussão enorme. Pode ser campanha... Sou contra campanha... Como é que isso aconteceu naquela época?

Reinaldo A estratégia de campanha de vacinação vem desde a varíola, e as campanhas de sarampo e a de poliomielite vêm em sequência. As pessoas que eram contra as campanhas alegavam razões como uso das campanhas para promover políticos inescrupulosos. Tinha a campanha e depois o entusiasmo desaparecia. Cuba já tinha feito dias nacionais de vacinação com grande sucesso quando eliminaram a poliomielite de Cuba. Então o Sabin propôs fazer o dia nacional de imunização no Brasil. A essa altura ascendeu ao Ministério da Saúde, como Secretário das Ações Básicas de Saúde, o João Batista Rizzi Jr. E o Rizzi foi um marco no programa de imunizações. Quando havia campanhas, essas eram mal planejadas, mal organizadas. Com exceção da varíola em que o Rizzi e o Ciro de Quadros estavam, que sempre foi bem organizado. A vigilância era muito ruim e as coberturas vacinais muito baixas, para sarampo e para outras doenças, inclusive poliomielite. A essa altura já era vacina oral, em gotinha, fácil de administrar. A ideia era do Sabin, tinha um fundamento técnico porque ele raciocinava que se inundasse o país num dia só com a vacina de poliomielite, o vírus selvagem ficaria sem espaço e poderia ajudar mais do que a ação individual. Então o Rizzi falou que era possível. E, no início, duvidei que fosse possível.

Marilia É mesmo?

Reinaldo Vacinar o país todo num dia só?! E o Sabin ainda detalhava: deve ser num sábado. Final de semana, de preferência no sábado porque durante a semana é mais difícil para as pessoas participarem. Foi feito um planejamento minucioso. Só que o Sabin também queria que fizesse uma pesquisa para poder comparar antes e depois. Era uma ideia, vamos dizer, naquele momento, era inoportuna. E teria que ser feito com muito mais cuidado, com muita mais ciência do que o Sabin estava apontando. Ele era um virologista, não epidemiologista. Nessa época a ideia de fazer a campanha sofreu 
uma oposição enorme. Dizia-se que era jogada política, era fogo fátuo e ia desestruturar os postos de saúde. Ao invés de melhorar, ia piorar porque ia focar nas campanhas. Em 1980, fui ser presidente da Sociedade Brasileira de Pediatria e fiz uma parceria muito boa com o Rizzi.

Ele era muito competente, tinha trabalhado no campo, escola da Fundação SESP. Esse pessoal ascendeu aos cargos passando pela ponta. Eu conheci o Rizzi lá na favela da Maré onde eu também trabalhei. Nós falávamos a mesma linguagem, coisa que não acontecia antes. Eu tive certa resistência aos dias nacionais de imunizações porque eu achava impossível. Propus uma semana, mas o Rizzi conversou comigo: "Não! É possível fazer em um dia”. E ele sabia o que estava falando porque a essa altura já tinha rede [de atenção básica]. Não era tão ampla quanto hoje, mas já tinha uma rede. E também a vacina podia ser aplicada por pessoas treinadas. Não precisava ser especificamente técnico.

Camacho A rede de frio nessa época era satisfatória?

Reinaldo Não, mas para campanha sempre melhorava.

Reinaldo Não era o ideal, mas era o que se tinha. E eu defendi os dias nacionais de imunização com a realidade: nós estávamos com a cobertura muito baixa. Não havia um panorama de que isso fosse resolvido com a rotina. Iria demorar um tempo enorme até a rede ser estruturada. Além disso, havia razões técnicas para isso. Mesmo que os postos de saúde funcionassem bem, o dia nacional de vacinação era bem indicado para controlar a pólio. E um dia me chamaram na ENSP, e a principal opositora, excelente epidemiologista que fazia tudo na melhor das intenções, fez uma oposição muito grande, e capitaneou todo o grupo lá da Fiocruz. Havia também gente contra por outros motivos. Coisas do tipo: "Reinaldo, você está mandando vacinar todo mundo contra poliomielite e se der algum problema você vai ser processado". E também gente que dizia "poliomielite é uma bobagem perto de desnutrição". "Vocês estão gastando muito dinheiro com prevenção de poliomielite quando tem problemas mais graves, inclusive a desnutrição, e outras doenças que são mais graves do que a poliomielite”. Eu argumentava: primeiro que a prevenção da poliomielite é mais fácil, com gotinha; segundo, a realidade: se quisermos resolver esse problema de coberturas através da estruturação dos postos, vamos levar dez a vinte anos ou mais. Nós não podemos deixar esse pessoal pegar poliomielite assim com uma maneira tão fácil de evitar ${ }^{4}$. Mas predominou o grupo que era a favor do dia de imunização. Devo dizer que na época o presidente era o João Baptista Figueiredo, uma pessoa também bastante hostilizada no meio médico... de um modo geral. E eu dizia "eu estou colaborando com o Ministério da Saúde, com o programa de vacinações. Não tem nada que ver com o governo, com o aspecto político". No Ministério eu falei "a colaboração da sociedade de pediatria está assegurada desde que não utilizem as campanhas com fins políticos”. Isso foi uma marca registrada que vem desde o início, que raramente foi contrariado. Eu já tinha experiência de interferência política que só serve para atrapalhar e desmoralizar. Então com isso o programa se impôs, os dias nacionais de imunização se impuseram pelo sucesso extraordinário. A incidência da poliomielite caiu verticalmente.

Marilia Eu me lembro que havia uma discussão também que a campanha funcionou porque já vinha caindo de qualquer maneira.

Reinaldo Totalmente sem fundamento!

Reinaldo Havia surtos localizados de poliomielite. O último antes de iniciar a campanha, que adquiriu uma dimensão maior, foi no Paraná e deu uma repercussão grande. Então o Rizzi chamou uma pessoa que se opunha às campanhas para fazer uma avaliação de custo-benefício. A conclusão é que era muito mais barato vacinar com a campanha do que com a rotina. Sem falar no resultado. E, ao contrário do que temiam muitas pessoas, isso deu prestígio ao programa nacional de imunizações, fortaleceu as ações preventivas, fortaleceu os postos de saúde que começaram a ficar mais bem estruturados. O posto de saúde que eu trabalhava era uma casa velha. Os centros de saúde começaram a ficar mais arrumadinhos, mais adequados.

Marilia E a rede de frio também, não?

Reinaldo A rede de frio foi melhorada porque [antes] a geladeira era usada para tudo, inclusive vacina. Eu lembro de uma epidemia de sarampo na Baixada Fluminense em crianças vacinadas, às vezes até com duas doses. Foi feita uma vistoria. Na geladeira tinha de tudo: sanduíches, refrigerantes... O transporte também não era adequado, mas a rede de frio foi melhorando. Foi criada a central de rede de frio ali no [bairro do] Caju, que contribuiu para uma logística adequada. Também os dias nacionais de vacinação deram certo porque a essa altura o Brasil tinha uma rede de comunicação que abrangia quase todo o território nacional. As emissoras de televisão alcançavam todos os estados. 
Com isso a mensagem era veiculada. Foi feito um planejamento muito adequado, muito minucioso pelo Rizzi. Explicava como formar a fila. Foi até ridicularizado por parte da imprensa. Resultado: ninguém teve dúvida do que fazer no dia, coisa que nunca tinha acontecido. E o Rizzi quando emitia uma nota técnica, uma orientação do Ministério da Saúde, era sempre com uma clareza cristalina. A área de comunicação sobre vacinas melhorou muito também.

Marilia Eu queria trazer um outro componente que é a questão do desenvolvimento tecnológico, e de Bio-Manguinhos que surgiu nessa época também.

Reinaldo Conforme eu estava falando são muitos componentes. No início dos anos 1980 houve um desabastecimento de vacinas e começaram a surgir surtos de difteria. Eu vou começar pela qualidade das vacinas. Nessa época eu estava na Sociedade de Pediatria. Eu divulgava as ações do Ministério da Saúde para os pediatras e lembro de um colega que me escreveu sobre isso... João Regis que trabalhava no hospital de doenças infecciosas de Recife. Eu falei com o Rizzi que eu sempre soube que essa vacina tríplice não protegia contra a coqueluche, mas parecia que também não estava protegendo contra a difteria. O Rizzi foi ver a qualidade, mas não tinha laboratório no Brasil capaz de apurar a qualidade da vacina tríplice. Então os testes foram feitos no Chile e, para nossa surpresa, não protegia contra difteria, nem tétano, nem coqueluche.

Marilia Era importada?

Reinaldo Nessa época o Laboratório Pinheiros, que era um pequeno laboratório, fazia uma boa vacina de difteria e tétano, mas não de coqueluche. Foi adquirido pela Sintex, que modernizou a fábrica, mas ficou produzindo uma vacina que não tinha eficácia. O Sintex ao invés de corrigir os problemas, fechou as portas e foi embora. Nós fomos obrigados a importar vacina. Daí surgiram duas iniciativas muito importantes: a criação do INCQS [Instituto Nacional de Controle de Qualidade em Saúde/Fiocruz] para controle de qualidade de vacinas, e o fortalecimento dos produtores nacionais, especificamente o Instituto Butantan e Bio-Manguinhos. Junto com o INCQS, contribuíram para melhorar a disponibilidade e a qualidade das vacinas. A vigilância [epidemiológica] era um desastre e eu não vou poupar palavras. A Anvisa [Agência Nacional de Vigilância Sanitária], a agência regulatória na época, era um desastre, era um ninho de ratos. Era uma corrupção descarada e não tinha credibilidade. A partir da gestão do Adib Jatene no Ministério da Saúde, o [Gonçalo] Vecina foi dirigir a Anvisa e houve uma virada e outros depois levaram adiante. Isso contribuiu para melhorar o processo produtivo. Agora, para produzir de acordo com as exigências da Anvisa, que segue um patamar internacional, está se criando um problema sério para os produtores dos países em desenvolvimento, não só o Brasil. Nós não temos os recursos das multinacionais para competir. Por outro lado, a OMS só reconhece a Anvisa como única agência confiável, apta a dar qualificação às vacinas. Então existe um jogo de exigência, que seria todo certo se os produtores estivessem recebendo os recursos necessários. Mas nos últimos anos as exigências aumentaram e os recursos minguaram, criando um impasse na área de produção. Mas isso já é o final da história. O fortalecimento do programa de imunizações se deve a muitas ações. Uma delas isoladamente não seria capaz de sustentar. E o prestígio do PNI [Programa Nacional de Imunizações] deve muito às campanhas de poliomielite e depois outras [doenças]. Porque até hoje não se consegue eliminar o estilo campanha para determinadas situações. Para o surto de sarampo agora no Norte, vamos ter de fazer campanha, vacinar população de todas as idades, senão não vai controlar o surto. Se ficar com ações pontuais vai ficar rolando lá o sarampo, como aconteceu no Nordeste, faz poucos anos. Nós demoramos para eliminar o sarampo no território nacional por causa do surto no Nordeste, e agora estamos tendo problema na fronteira com a Venezuela e casos da Europa.

Reinaldo A vigilância também melhorou. Todo mundo reclama da vigilância, mas eu acho ótimo porque fico lembrando de como era. Não tem comparação! Você hoje tem informações que podem ter falhas, mas é informação coerente sobre a ocorrência de doenças de notificação obrigatória. Não se tinha quase nada e os dados não eram confiáveis. E esses são.

Marilia Toda essa parte de capacitação e treinamento foi fruto dessa época também. Foram os treinamentos no programa de vacinação e de vigilância epidemiológica. Eu tenho maior orgulho porque participei da equipe que montou o material de treinamento e até hoje esse material é reciclado e reutilizado. Isso teve um lado de mexer no serviço de saúde por dentro.

Reinaldo Os manuais do Ministério da Saúde ajudaram muito. Eu tive a honra de coordenar alguns desses manuais. O manual da vacinação ${ }^{5}$ sempre foi muito magrinho, eu acho que devia ser 
mais robusto. Mas tem o manual dos CRIEs (Centros de Referência de Imunológicos Especiais) para atender populações especiais, e cada uma dessas atividades tem um manual ${ }^{6}$. O manual ajuda muito como documento básico aos treinamentos e são revisados periodicamente. $\mathrm{O}$ manual de vigilância acabou de ser revisado. Então é um conjunto em que entram recursos humanos, treinamento e tudo mais.

Camacho Nós lidamos na época da varíola com uma vacina altamente reatogênica. Em que momento os eventos adversos passaram a ter maior visibilidade?

Reinaldo Eu não sou especialista em psicologia de multidões, mas acho que todo movimento gera um contra-movimento, mesmo que seja um movimento melhor do mundo. Se não gerar um contra movimento é porque a ideia não tem importância ou ninguém tá ligando. Mas quando a ideia é bem formulada, a toda ação corresponde uma reação. A vacina de varíola, desde o início das vacinações na Inglaterra, sofreu uma oposição enorme de grupos antivacina.

Marilia E no Brasil, não?

Reinaldo Era muito mais forte do que é agora, apesar das fake news, inclusive porque tinha algum fundamento. Esse é o pior tipo de problema, quando eles têm fundamento. Quando não têm fundamento, as fake news se esgotam por si mesmo. A vacina de varíola naquela época [fim do século XVIII] era produzida artesanalmente e tinha contaminações. Às vezes fazia vacinação pessoa a pessoa e podia inocular, por exemplo, outras doenças. As pessoas que se opunham tinham algum fundamento em ter medo da vacina. Não tinha como negar que houvesse efeito colateral. Se bem que nessa época se escondiam os eventos adversos. Ninguém falava sobre isso. Quando a vacina chegou no Brasil também tinha um grupo pró e um grupo contra. Eu penso que a internet faz muito ruído, mas o efeito de forma geral, com algumas exceções, não é muito grande porque são ideias e notícias tão inverossímeis, tão absurdas e sem fundamento, que se esgotam.

Mas quando é que se cria o problema? Quando tem médico envolvido na acusação. Uma vez me pediram para analisar a situação em uma cidade do interior que era contra a vacinação da BCG. Eu já tinha experiência e perguntei quem era o médico que estava contra? Não deu outra. Tinha um médico lá, de prestígio, que era contra a BCG baseado no fato de que os americanos não faziam a BCG, como não fazem de rotina até hoje. Ele também recomendava: “Não, BCG não é para fazer”. Isso foi equacionado conversando com o médico, naturalmente. O caso da Inglaterra, do primeiro evento mais grave nessa linha foi com lesão cerebral depois da vacina de coqueluche, que tinha algum fundamento. Um trabalho de uma pessoa de grande prestígio, publicado numa revista importante, mostrou lesão cerebral em criança que tinha tomado vacina de coqueluche. Após a vacina de coqueluche algumas crianças desmaiam, ficam hiporresponsivas, algumas têm convulsões. Muitas crianças têm febre alta. É uma vacina que todo mundo fica até hoje com um pé atrás. Quando ele disse que tinha caso de lesão cerebral pela vacina de coqueluche, afetou o programa de vacinação contra coqueluche na Inglaterra. Então ocorreu uma grave epidemia de coqueluche, com muitas complicações, aí se voltou a vacinar. Semelhante ao que aconteceu com o Oswaldo Cruz, que vacinou contra a varíola, a população se revoltou, a epidemia não terminou, e eles foram vendo que quem tinha sido vacinado não pegava varíola e quem pegava varíola não tinha se vacinado. Então a vacinação voltou pelo efeito demonstração, que é o melhor argumento contra boatos, quer dizer, mostrar o que acontece na realidade. O outro episódio grave foi com o Wakefield [médico inglês] relacionando autismo com vacina tríplice viral 7.

Marilia Isso foi fraude!

Reinaldo É, mas ninguém sabia que ele tinha fraudado. Era um médico de grande prestígio, trabalhando num hospital importante na Inglaterra e, segundo me falou o David Salisbury que era diretor de saúde na Inglaterra nessa época, era uma pessoa muito eloquente, que falava muito bem na televisão. E o Salisbury que é um homem até inteligente, muito interessante, cometeu o erro de polemizar com o Wakefield. A pior coisa que se pode fazer numa situação dessas é polemizar porque dá mais credibilidade. Quer dizer, o que ele falou tem fundamento porque se não tivesse não vinha o diretor de saúde pública para debater o assunto. Após a polêmica, as coberturas da vacina tríplice viral caíram na Inglaterra. Depois disso, ocorreram epidemias de sarampo e de rubéola, e as coberturas começaram a melhorar de novo. E novamente o que acontece é a melhor resposta que, às vezes, demora algum tempo.

Marilia E, às vezes, nesse meio tempo criancinhas morrem. 
Reinaldo Sim, epidemias por causa de falta de vacinação. Eu lembro que no início nem se falava em evento adverso. Era tanta doença que não tinha lugar para falar em evento adverso. Depois o Ministério da Saúde me contratou para fazer esse manual de eventos adversos que, como documento, como livro-texto, que eu saiba é o primeiro que foi feito no mundo ${ }^{8}$. Ninguém tinha um documento unificado e didático falando de eventos adversos com todas as vacinas. Acho que o Brasil foi o primeiro a fazer. E ali está dito com toda clareza: vacinas têm, como qualquer produto, benefícios, reações adversas, mas as vacinas que são utilizadas foram estudadas e feito um balanço (de risco-efetividade). Ninguém escondeu os efeitos adversos. Isso é muito importante e ajuda a dar credibilidade ao programa. Lembro quando houve os primeiros casos da doença viscerotrópica em 1998-1999, publicado em 1999, a evidência indicava que era da vacina de febre amarela. A vacina de febre amarela raramente pode causar um evento adverso [grave]. Na verdade, não é uma reação, é uma invasão do indivíduo pelo vírus vacinal como se fosse a doença febre amarela, por razões que não se conheciam. Não houve alteração genética do vírus vacinal, pelo menos não alterações genéticas que justificassem. Estranhamente, a imunidade adquirida não está comprometida nesses casos. Essa doença não tem sido descrita em imunocomprometidos, que já é contraindicação. Mas não se sabia nada sobre isso até os estudos que fizemos junto com um americano chamado Steven Seligman, que trabalhava num grupo de genética ligado a doenças infecciosas na Fundação Rockefeller. Nós estávamos assistindo num congresso de imunologia em Ouro Preto, há cerca de 5 anos, à palestra de onde surgiu a ideia do [Jean Laurent] Casanova, que tem muitos trabalhos nessa linha de genética e suscetibilidade a doenças. Ele chama de "buracos gênicos", quer dizer pequenas mutações que fazem um desastre. Então nós "bolamos" um protocolo de investigação desses casos, que aplicamos pela primeira vez no ano passado num caso de Macuco no Estado do Rio de Janeiro. É um caso bem documentado de doença viscerotrópica numa jovenzinha que ficou muito grave, mas não morreu. Nós fizemos um estudo genético com biópsia de pele, coleta de saliva, sangue, com termo de consentimento. Da família coletamos saliva e verificou-se que essa jovenzinha aparentemente normal tinha mutação dupla no receptor de interferon alfa, que é a primeira barreira contra o vírus. Esse pessoal da Rockefeller ficou entusiasmado e um resumo do trabalho vai ser apresentado num congresso na Europa. Inclui o grupo de Bio-Manguinhos que participou da pesquisa. Nós descobrimos uma coisa que ninguém tinha descrito. As pessoas desconfiavam que devia ser uma coisa ligada ao início da resposta imune, que é um evento que ocorre logo depois da aplicação da vacina. Mas ninguém sabia realmente. Agora em pelo menos um caso nós vimos com receptor de interferon alfa. Da família tinha essa moça que era homozigota, que era a mutação, os pais eram heterozigotos, um irmão não tem mutação nenhuma e o outro é heterozigoto. Só quem não pode vacinar é o homozigoto.

Reinaldo Quando tivemos esse resultado escrito fomos falar com a família. Ao Jean Laurent Casanova eu perguntei que orientações ele daria para as futuras vacinações da paciente e seus familiares. Ele nos orientou por escrito e a Lurdinha [Dra. Maria de Lourdes Maia, chefe da Assessoria Clínica de Bio-Manguinhos] me falou que nós devíamos ter uma pessoa aqui especialista em imunodeficiência primária para participar da atenção a essa moça nos anos seguintes. Estudamos um caso só e vamos estudar agora um caso de Belo Horizonte, cuja irmã tomou a vacina de febre amarela e morreu. A irmã sobrevivente tomou a vacina, passou mal, mas não morreu. Poderemos ver se a mutação é a mesma. É bem possível que haja mais de uma mutação responsável e a ideia, embora não seja fácil, acredito que não seja impossível, é encontrar um marcador biológico que permita identificar essas pessoas e incluir, por exemplo, no teste do pezinho; quando a criança nasce ou então quando for a primeira vez no posto de saúde. Nossa ideia é fazer um kit diagnóstico também como uma maneira de convencer as pessoas. A proposta desse kit implicou a necessidade de um acordo jurídico já que ele envolveria patente. Aí entra um outro grande gargalo, um dos problemas que nós estamos tendo agora. Esse meu protocolo ficou uns três meses na área jurídica de Bio-Manguinhos e da Fiocruz. Não implica despesas especiais, o custo é um pouco mais de 200 mil Reais por ano. Para pesquisa isso é muito pouco. Não tem risco para Bio-Manguinhos. Se não der certo, a parceria pode ser desfeita a qualquer momento.

Marilia Esse relato que você fez agora é muito interessante, que mostra uma capacidade da ciência brasileira fantástica e que tem sido ou menosprezada, ou sabotada, e que cresceu também junto com o programa de imunizações. Eu acho que se aprendeu nesse processo a fazer pesquisa, a avaliar custo-efetividade, a avaliar impacto de ações. Eu sou epidemiologista, por isso eu vejo mais esse 
lado... desenvolver tecnologia, desenvolver ações na atenção primária. Que a gente tem uma enorme capacidade, certo?

Reinaldo Sim, capacidade eu não tenho dúvidas, mas não temos suficiente experiência. E não temos uma massa crítica de tamanho suficiente. Por outro lado, há outras coisas que estão criando problemas pro desenvolvimento tecnológico que não implicam dinheiro. Claro que o dinheiro é importante. Mas do jeito que as coisas funcionam aqui no Brasil, mesmo com muito dinheiro não vai funcionar bem. Não é possível que um procedimento que deveria demorar seis meses tenha levado três anos!

Camacho Junto com a vacinação se estruturou uma vigilância que funcionou bem e que envolvia também eventos adversos. Você pode falar um pouco sobre isso?

Reinaldo Pois é, o programa de poliomielite serviu de modelo para várias outras coisas. Foi o modelo de vigilância de reações adversas. Foi um aprendizado também. Quando olhamos os dados de poliomielite associado à vacina, vemos umas coisas que parecem absurdas. Um período que tinha notificação demais, depois diminuiu. Eu não cheguei nesse grupo desde a primeira reunião. Quando eu cheguei falei: "tem de ter uma definição de caso". Cada caso era um caso e não tinha uma definição. Havia uma certa hipertrofia de notificação de poliomielite associada à vacina. Com a definição isso diminuiu, ficou mais compatível com a realidade. É claro que toda a classificação e toda definição têm limitação, mas se não tiver fica confuso. Quando houve a decisão de erradicar a poliomielite, a vigilância de poliomielite aumentou e aumentou o número de casos. Aquela epidemia do Nordeste (1986) de que todo mundo fala, eu tenho dúvidas porque a vigilância melhorou ao mesmo tempo. Começou-se a buscar mais os casos. Eu lembro que a Bahia não tinha notificação de poliomielite. Aí mandaram um grupo lá e estava cheio de poliomielite que não era notificado. Às vezes a melhora da vigilância dá a impressão de que a doença está piorando. A mesma coisa aconteceu com o sarampo. À medida em que aumentou o programa de imunização contra o sarampo o número de casos também foi aumentando. Parecia um absurdo, mas é que a vigilância também foi melhorando.

Camacho Parece que os progressos na vigilância viraram subproduto da campanha de vacinação e não o contrário, como deveria ser.

Reinaldo Verdade. Quando começaram os dias nacionais de vacinação os dados eram muito falhos. Então eu propus na época quando estavam iniciando as campanhas que houvesse notificação também pelos serviços, não somente pelos postos de saúde, mas também pelos hospitais da rede. Eu lembro que o [Daniel] Becker falou uma coisa muito interessante: "Reinaldo, você também aí pode ter uma porção de casos que não são poliomielite, que irão ser notificados. Você vai perder em qualidade, enquanto que esses casos que nós estamos recebendo são de hospitais de referência, e então não há dúvida sobre o diagnóstico". Eu não preciso saber de todos os casos para saber o comportamento da doença. O perfil da doença, do lugar, permitia planejar a vacinação para menores de cinco anos. Era baseado nos dados. Não eram todos, mas havia o perfil.

Reinaldo Eu acho muito importante que os programas de imunização sejam integrados com as outras ações de saúde pública, inclusive na área materno-infantil. Eu penso que poderíamos melhorar muito na direção de integrar melhor. Mas todas as vezes que tomaram iniciativa de propor a descentralização do programa de imunização eu fui contra.

Reinaldo Quem estava propondo isso não estava preocupado com o programa de imunizações. Estava preocupado em fazer acordos regionais de compra de vacinas por pessoas que depois vão financiar campanhas políticas. Ou então o próprio programa local serviria de chamariz para quem propôs. Por exemplo, introduziu-se vacina de varicela em Santa Catarina, em Florianópolis, e eu disse: "como é que vai implantar uma vacina dessa num lugar só?". Foi o que fizeram, mas não se sustentou. Quer dizer, esse tipo de ação só vai ajudar a desestabilizar o programa.

Marilia Reinaldo, e a questão da vacina de dengue, o que você acha?

Reinaldo É um exemplo típico do que acontece com a pressão da indústria. É claro que é uma vacina de interesse de boa parte do mundo. E teve patrocínio de organismos internacionais, como a OMS. Mas os documentos que eu fui recebendo sobre a vacina de dengue, lendo os artigos e estudando muita coisa que já tinha sido publicada, eu fiquei com muita dúvida.

Reinaldo Quando surgiu a vacina de dengue, as reuniões nos congressos eram para promover a vacina! Eu acho que fiquei falando isoladamente sobre o desconhecimento que se tinha de vários aspectos da vacina. A vacina é feita no vetor vivo, vacina de febre amarela, que tem eventos adversos 
graves. Se essa vacina contra dengue daria eventos adversos graves, para mim não estava completamente esclarecida. Também a duração da imunidade era crítica porque quando há queda de anticorpos a incidência de dengue grave aumenta. E os resultados dos trabalhos davam margem à dúvida. No entanto, se apresentava a vacina como uma coisa que tinha resolvido o problema da dengue. Eu conversei inclusive no programa de imunizações, chamando a atenção para as dúvidas e riscos de introduzir essa vacina em larga escala. Depois verificou-se que tinha uma questão desde o início, da pouca imunogenicidade em baixa idade. Depois surgiu uma questão de que dengue hemorrágica apareceu com frequência maior em crianças que já tinham tomado a vacina do que naquelas que não tinham sido vacinadas. Então se recomendou a vacina a partir de nove anos de idade 9 . Eu penso, como se diz, data venia, que a sociedade brasileira de pediatria se precipitou porque logo incorporaram a vacina ao calendário de vacinação.

Camacho A SBIm [Sociedade Brasileira de Imunizações] acompanhou?

Reinaldo A SBIm também. Mas a SBP [Sociedade Brasileira de Pediatria] me marcou particularmente porque lida basicamente com crianças, que é uma faixa em que a vacina não deve ser utilizada. Depois se expandiu esse conceito de que não são só as crianças. Pessoas suscetíveis que nunca tiveram dengue também não devem fazer a vacina.

Marilia Então para que, né?

Reinaldo Então ficou uma vacina com problemas demais para poder ser implantada de rotina ou aplicada em massa. Fui a favor de um estudo mais localizado e de duração maior para ter um esclarecimento sobre as dúvidas pendentes. Mas nessa altura acho que não tem muita dúvida.

Reinaldo Houve um açodamento enorme de apresentar a vacina como pronta, e dos grupos que se deixaram envolver com muita facilidade. Então isso é um aspecto também que deve preocupar. Manter neutralidade é impossível porque quem diz que é neutro é mentiroso... mas a gente tem de pelo menos buscar a neutralidade.

Marilia E manter a qualidade científica. Ler o artigo até o final.

Camacho Parte da robustez do nosso programa de imunização se traduziu na formação e consolidação de um comitê técnico assessor de imunização (CTAI) prestigiado, formado por pessoas de grande experiência, com notório saber 10. E você acompanhou desde o início. Como você vê os comitês técnicos assessores de imunização em geral, e o nosso em particular?

Reinaldo O comitê foi se fortalecendo com o tempo. O ideal é que cada estado tivesse um comitê assessor para ver as questões específicas de cada estado, mas pelo menos em nível nacional nós temos um grupo forte. Tem alguém neutro, alguém que não tem conflito de interesses? Eu digo que não.

Reinaldo Todo mundo tem conflito de interesses e eu falei isso uma vez numa reunião internacional. Eles queriam que as pessoas do CTAI não tivessem conflito de interesses, sendo de preferência pessoas do setor universitário. Eu falei "isso é uma ilusão porque no Brasil, pelo menos, o único grupo que talvez a gente possa dizer que seja isento de conflito de interesses é a Anvisa. Todos os demais têm algum interesse. O importante é a transparência”.

Marilia Reinaldo, eu acho que com isso a gente conclui primeiro o motivo da entrevista. A gente tem de recuperar a história que nós temos e que às vezes não é fácil de recuperar, e que acho que foi um dos objetivos aqui hoje. Trazer de volta essa história para que novas gerações conheçam o que foi feito. Eu acho que por isso nós estamos aqui no sábado. Porque nós acreditamos no que estamos fazendo. 


\section{Colaboradores}

L. A. B. Camacho contribuiu na realização da entrevista, transcrição e revisão da transcrição. M. S. Carvalho contribuiu na realização da entrevista e revisão da transcrição. R. M. Martins contribuiu na concessão da entrevista.

\section{Informações adicionais}

ORCID: Luiz Antonio Bastos Camacho (00000003-4656-1914); Marilia Sá Carvalho (00000002-9566-0284); Reinaldo de Menezes Martins (in memorian).

\section{Referências}

1. Rodrigues E. Zilda Arns: uma biografia. Rio de Janeiro: Anfiteatro; 2018.

2. Martins RM. Pediatria preventiva. Pediatr Mod 1974; 8:30-40.

3. Martins RM. Vacinas polissacárides. Pediatr Mod 1996; 32:470-94.

4. Martins RM. Dias Nacionais de Vacinação. Skopia 1984; 2:13-6.

5. Departamento de Vigilância das Doenças Transmissíveis, Secretaria de Vigilância em Saúde, Ministério da Saúde. Manual de normas e procedimentos para vacinação. Brasília: Ministério da Saúde; 2014.

6. Martins RM, Silva Junior JB, Maia MLS, Ganter B, Schatzmayr HG, Freire LMS, et al., organizadores. Manual dos Centros de Referência de Imunobiológicos Especiais. 2a Ed. Brasília: Fundação Nacional de Saúde; 2001.

7. Godlee F, Smith J, Marcovitch H. Wakefield's article linking MMR vaccine and autism was fraudulent. BMJ 2011; 342:c7452.

8. Departamento de Vigilância das Doenças Transmissíveis, Secretaria de Vigilância em Saúde, Ministério da Saúde. Manual de vigilância epidemiológica de eventos adversos pós-vacinação. 3a Ed. Brasília: Ministério da Saúde; 2014.

9. World Health Organization. Dengue vaccine: WHO position paper - September 2018. Wkly Epidemiol Rec 2018; 93:457-76.

10. Secretaria de Vigilância à Saúde, Ministério da Saúde. Portaria no 11 , de 3 de setembro de 2003. Diário Oficial da União 2003; 5 set. 